\title{
MEASURING BRAND VALUE BASED ON CUSTOMER DATA: THE SURVEY FROM SMARTPHONE MARKET IN HO CHI MINH CITY, VIETNAM
}

\author{
Ai Tran Huu \\ Nguyen Le Thi Minh \\ Dao Mai Thi Hong \\ Van Hien University, Ho Chi Minh City, Vietnam
}

This study uses structural equation modeling (SEM) to find the correlation between the variables of the brand value model following (David Aaker, 1991) and using the customer data from the survey of 354 customers in Ho Chi Minh City, Vietnam. The results show the impact level of the factors that constitute the brand value of smartphones in general as well as the brand value of particular smartphones. The findings may be found important for building and developing brand strategies by Vietnamese manufacturers and retailers.

Keywords: brand value; brand strategy; smartphones; customer survey; Ho Chi Minh; Vietnam
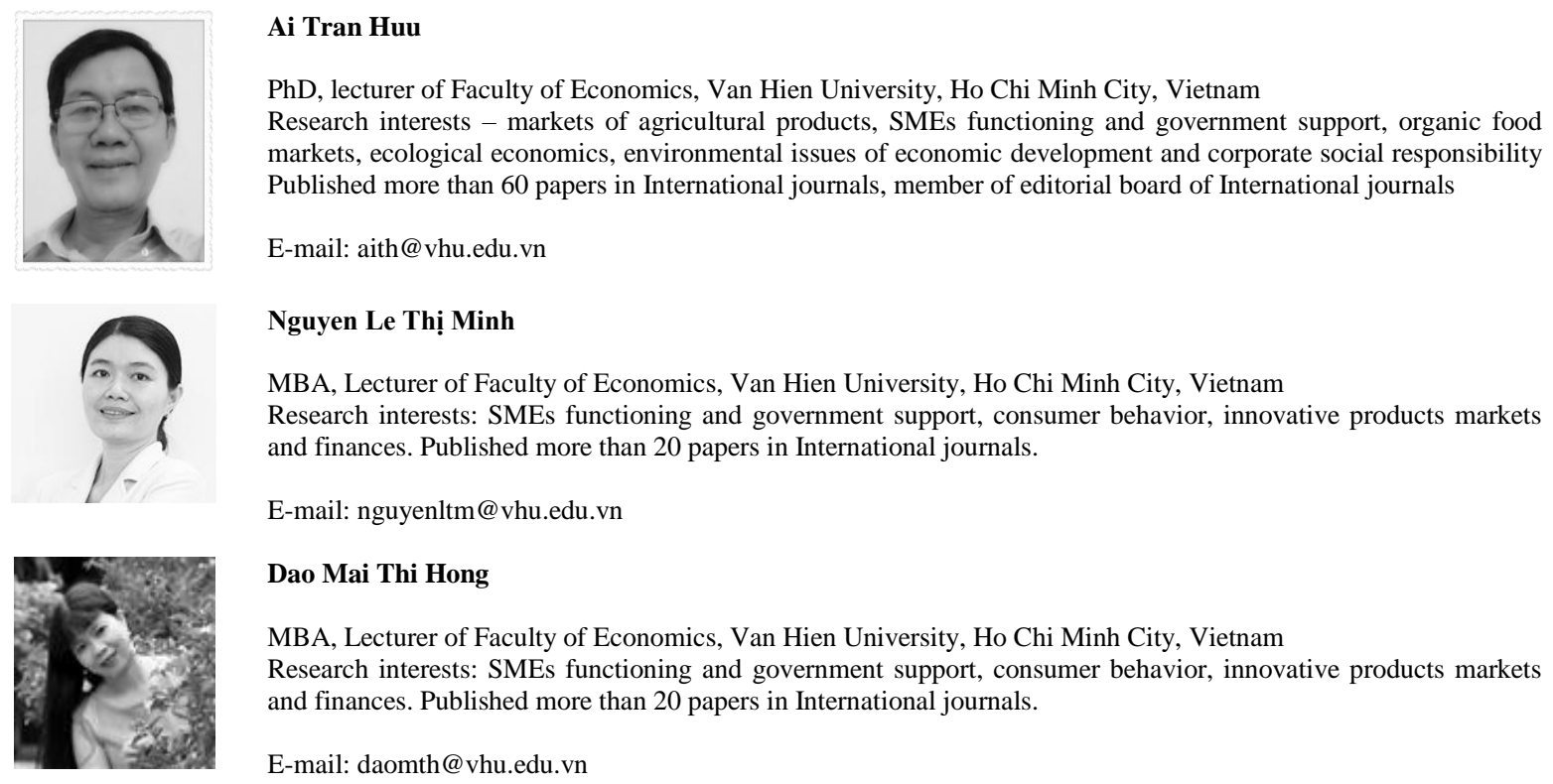

MBA, Lecturer of Faculty of Economics, Van Hien University, Ho Chi Minh City, Vietnam Research interests: SMEs functioning and government support, consumer behavior, innovative products markets and finances. Published more than 20 papers in International journals.

E-mail: daomth@vhu.edu.vn 


\section{Introduction}

Vietnamese smartphone market today is gradually changing with the especially significant role played by Chinese smartphone companies such as Xiaomi or Huawei that are increasingly dominating and even going ahead "the big guys" such as Samsung or Apple. The presence of Sony, HTC, BlackBerry at Vietnamese mobile market is much weaker, thus making way and freeing market space to newly emerging names. Prejudice or love for a particular brand is still out there, but we can also observe gradual disappearance of the once well established and very popular brand names, and their replacement by rookies is showing all of us the new face of the market.

According to the statistics generated by the Counterpoint Research, Vietnam's smartphone market has risen by 2 digits in Q2/2018. Notably, this growth took place mainly thanks to Chinese smartphones. Overall, the sales at Vietnamese smartphone market have increased by $11 \%$ over the same period last year, and this is the strongest growth rate since Q4/2016. Smartphones account for nearly 52\% of all phones sold during Q2/2018. The universal phone segment is down by $19 \%$ as compared to the same period in the previous year, but it remains to be a relatively attractive segment of Vietnamese market. Also, Samsung is still the giant leading Vietnamese smartphone market with its impressive $37 \%$ market share. However, its market share has actually decreased by $4 \%$ as compared to $41 \%$ it used to have back in Q2/2017. Samsung accounts for more than one third of all the smartphones at the market. Samsung's Galaxy J line is still selling well and is accounting for $60 \%$ of total Samsung's sales in Vietnam.

In the context of an escalating trade war between the USA and China, the yuan has shown signs of weakening. Therefore, Chinese products are becoming cheaper and cheaper when sold in Vietnam. This will further benefit Chinese brands, which currently enjoy the $39 \%$ market share in Vietnam. Chinese smartphone companies are actively offering different variants of phones in the mid-range segment with enough storage capacity to attract customers. The most active brands in this regard are Xiaomi or Huawei, Oppo is following the same strategy. The index of Vietnamese smartphone market penetration is quite low and this shows that the growth potential of Vietnamese smartphone market is still very high. For example, such brands as Symphony MGT, HIYA and Vfone, although still less known to general public, are actively approaching the local market because of its great potential.

Although the smartphone market is experiencing strong growth, the market of telephones in general is declining by $6 \%$ as compared to the same period last year. The main reason is for this is the sharp decline (about 19\%) in the popular phones segment. In addition, domestic brands are starting to demonstrate great financial potential, like Vingroup with its $\mathrm{V}$ smart product line, which is planning to attack the smartphone marketplace with the cheap smartphones in order to fill in the gaps at Vietnamese smartphone market. In such a context, brand competition is an extremely important factor capable of determining success and failure of manufacturers and other related businesses.

Trademarks in general and customer-based brand values in particular are not exactly new ideas for contemporary marketing research, however, studies on this issue are still rather few in Vietnam. In particular, when it comes to the smartphone market in Vietnam, the topic of customer-based brand value is still very new, with just a few works being published. Thus, the subject area of customer-based brand value at Vietnam's smartphone market aims is still at the stage of measuring the potential impacts of various components of brand value on the 


\section{MEASURING BRAND VALUE BASED ON CUSTOMER DATA}

entire brand value. For this very reason, the outcomes of this survey would be highly valuable not only for researchers but also for administrators responsible for development of brand strategies and policies for smartphone brands present at Vietnamese market.

\section{Theoretical basis and hypotheses}

The traditional view on brand as such be the belongs to the American Marketing Association (AMA): "Brand is a name, symbol, style or combination of elements that aims to identify a manufacturer's product or service and distinguish it from competitors' brands. "The general view of branding is that brand is not just a name or an icon, but more complicated (Davis, 2002). Branding is always a combination of tangible and invisible attributes (Levitt, 1981). Branding is an abstract concept, an intangible asset, presents in consumer's mind, accepted and trusted by the construction business and the consumer, the "soul" part of the job.

Lesser et al. (1995) proposed five components of brand value: (1) perceived quality, (2) perceived equity, (3) brand impression, (4) customer brand trust and (5) customer impressions of the brand.

Keller (1993, 1998) argued that it's all about customers' knowledge (Brand Knowledge) about the brand/trademark. Brand value in customers' evaluation covers different effects that brand knowledge gets from customer feedback as response to brand's marketing Keller (1998). This customer knowledge consists of two main components: (1) Brand awareness and (2) Brand image. This model clearly shows the strength of any brand lies in what customers perceive, feel, see and hear about the brand, as a result of consumer experience over time.

According to David Aaker (1991), brand value is a multidimensional concept. And also, brand value is an intangible set associated with brand name and symbol, contributing to increase or decrease in the value of a product or a service for the customers. Aaker's brand value theory is believed to offer a useful foundation for brand management and growth. Brand value has 5 components: (1) Brand awareness, (2) Perception of quality, (3) Brand association, (4) Brand Loyalty and (5) Other Proprietary Brand Assets such as patents, copyrights, trademarks, industrial designs, registered brand names and so on.

\section{Scale of measurement and research model}

\section{Perceptual quality}

Perceptual quality (PQ) is a fundamental element of brand value (Farquhar, 1989). This is customer's perception of the entire product quality, the difference between the total value of what customers received and the values they expect from a product (Zeithaml, 1988). Perceived high quality gives customers a reason to buy a brand, allowing brands to distinguish themselves from competitors; it is also a solid basis for expanding market share by using a common brand for many types of products. Based on the definition and the role of perceived quality, the following hypothesis has been formulated:

H1: Perceived quality has a positive effect on brand value. 


\section{Brand awareness}

Brand awareness (BAW) is an important component of brand value. It refers to the ability of a customer to recognize or remember the brand as a component of a certain product (Aaker, 1991). Brand awareness helps customers become familiar with the brand and helps them care about it at the time of purchase. Buyers often choose to buy brands that they know well because they feel more secure. Usually a well-known brand will be more reliable and the quality will be higher. Therefore, the following hypothesis is suggested:

$\mathrm{H} 2$ : Brand awareness has a positive impact on brand value.

\section{Brand association}

Brand association (BAS) is anything "linked" in customer memory with a certain brand (Aaker, 1991). These are stored directly or indirectly in customers' memory and are associated with brands or brand owners (Aperia, 2004). Customers will immediately think of one or a few features of a brand when the brand is mentioned. Brand association creates value for the company and its customers by: providing information; creating positive attitudes and emotions; establishing reasons to buy products; distinguishing and locating brands. Based on the concept and the role of brand association, the following hypothesis is suggested:

H3: Brand association has a positive impact on brand value.

\section{Brand loyalty}

Brand loyalty (BL) is the essence of brand value (Aaker, 1991). Brand loyalty is a measure of customer engagement with the brand. When brand loyalty is high, customers are less likely to switch to another brand just because of a lower price. Also, loyal customers tend to purchase more frequently (Bowen \& Shoemaker, 1998). The existence of loyal customers reduces the opportunity for both the closest and also the newly emerged competitors. In addition, loyal customers give the company a huge benefit by bringing out its products to other potential customers (Assael, 1995). Based on the importance of brand loyalty, the suggested hypothesis is stated as follows:

H4: Brand loyalty has a positive impact on brand value

\section{Product knowledge}

Product knowledge (PK) is a set of consumer perceptions of a certain product (Beatty $\&$ Smith, 1987). The tier of knowledge about products has its impact on consumer trends. When consumers understand the product well enough, they instantly become several steps closer to purchase planning as opposed to the consumers who are still at the research phase (Peter \& Olson, 1996). Therefore, the following hypothesis is suggested:

H5: Understanding products have a positive impact on brand value.

\section{Brand equity}

Brand equity (BE) is the value added to products and services (Kotler, 1996). This value is expressed through the way customers think, feel, act positively in relation to a brand and through the ability to value, win market share, and profitability that brands can bring for business. According to David Aaker: "Brand asset is a set of intangible assets associated with the brand name and symbol, which contributes to adding or reducing the value of a product 


\section{MEASURING BRAND VALUE BASED ON CUSTOMER DATA}

or service to the company and company customers". Therefore, the following hypothesis is offered for consideration:

H6: Brand equity has a positive impact on brand value.

\section{Research Methods}

Research methods used here are mixed research methods. The objects of the survey are customers using smartphones and residing in Ho Chi Minh City. Tabachnick \& Fidell (1996) suggested that the sample size should be ensured following the formula: $n>=8 \mathrm{~m} \times 50$. Selecting the sampling by convenient method for our particular case ensures the relative appearance of smartphone brands, using large market shares in Vietnam market at the time of the survey. The method of data collection is through questionnaires.

The survey team went to the smartphone selling points in districts $1,3,5$ and Phu Nhuan in Ho Chi Minh City, and there distributed questionnaires to customers. It normally took around 30 minutes to fill in the questionnaires and then they were collected back.

Each question was measured on a 5-point Likert scale. Data processing tool used in the study is SPSS Amos 24.0 software with the main tools being: Cronbach's Alpha; Exploratory Factor Analysis (EFA); Analysis of variance (AV); Confirmatory Factor Analysis (CFA) and Structural Equation Modeling (SEM).

400 surveys were initially distributed, 369 copies were collected back for further data entry processing. 15 samples were considered invalid. These rejected samples did not provide sufficient information or information was removed because the respondent hit the same type of options for all the questions. As a result, 354 samples were considered to be satisfactory for further data analysis.

\section{The results of testing the theoretical model}

\section{Preliminary assessment of scales}

The scale of components of the brand value (PQ, BAW, BAS, BL, PE and BE) and the whole brand value (BV) all have Cronbach's alpha larger than 0.6 and the correlation coefficients of the observed variables are higher than the 0.4 limit. Therefore, the observed variability of the scales is kept for EFA analysis.

Table 1 - Description of the survey sample

(Source: authors' survey)

\begin{tabular}{|c|c|c|c|c|c|c|c|}
\hline \multicolumn{2}{|c|}{ Gender } & \multicolumn{2}{c|}{ Age } & \multicolumn{4}{c|}{ Area of residence } \\
\hline Male & Female & $18-30$ & $>30$ & District 1 & District 3 & District 3 & $\begin{array}{c}\text { District Phu } \\
\text { Nhuan }\end{array}$ \\
\hline 186 & 168 & 259 & 95 & 96 & 117 & 70 & 71 \\
\hline \multicolumn{2}{|c|}{$\sum 354$} & \multicolumn{2}{|c|}{$\sum 354$} & \multicolumn{5}{c|}{$\sum 354$} \\
\hline
\end{tabular}


Table 2 - Cronbach Alpha results, aggregate reliability and total variance extracted from the research key concepts

(Source: authors' survey)

\begin{tabular}{|c|c|}
\hline BAW & Brand awareness $(\mathrm{BAW})(\alpha=0.855 ; \mathrm{CR}=0.857 ; \mathrm{AVE}=0.699)$ \\
\hline 1 & I know smartphone brands \\
\hline 2 & I can easily distinguish one smartphone brand from the others \\
\hline 3 & I can identify the smartphone brand logo quickly \\
\hline 4 & I can remember and recognize the typical colors of smartphone brands \\
\hline 5 & When it comes to smartphone brands I easy visualize them \\
\hline BAS & Brand association $(\mathrm{BAS})(\alpha=0.884 ; \mathrm{CR}=0.882 ; \mathrm{AVE}=0.692)$ \\
\hline 6 & I think the smartphone brand I choose has the features of high expertise level \\
\hline 7 & $\begin{array}{l}\text { Only the smartphone brand I choose has this unique feature that other smartphone } \\
\text { brands do not }\end{array}$ \\
\hline 8 & I think that the smartphone brand I choose will bring me some fresh experience \\
\hline 9 & In my opinion, the smartphone brand I choose brings what I desire \\
\hline 10 & In general, the smartphone brand I choose always has the quality guaranteed \\
\hline BE & Brand equity $(\mathrm{BE})(\alpha=0.872 ; \mathrm{CR}=0.876 ; \mathrm{AVE}=0.830)$ \\
\hline 11 & The smartphone brand I choose is energy efficient \\
\hline 12 & The smartphone brand I choose is easy to use \\
\hline 13 & The color of smartphone brands I choose is very eye-catching and attractive \\
\hline 14 & $\begin{array}{l}\text { The smartphone brand I choose has regular updates and the newest, most advanced } \\
\text { features }\end{array}$ \\
\hline BL & Brand loyalty $(\mathrm{BL})(\alpha=0.885 ; \mathrm{CR}=0.887 ; \mathrm{AVE}=0.723)$ \\
\hline 16 & This smartphone brand is my first choice \\
\hline 17 & $\begin{array}{l}\text { I will not buy another smartphone brand if this smartphone brand is available at the } \\
\text { shop }\end{array}$ \\
\hline 18 & I think I am a loyal customer of this smartphone brand \\
\hline 19 & I will continue to use this smartphone brand for a long time \\
\hline PQ & Perceptual quality $(\mathrm{PQ})(\alpha=0.856 ; \mathrm{CR}=0.857 ; \mathrm{AVE}=0.657)$ \\
\hline 20 & I like the type of smartphone brand I just bought. \\
\hline 21 & I feel comfortable using the smartphone I just bought. \\
\hline 22 & I feel secure using the smartphone brand I bought \\
\hline 23 & I am satisfied with the service of the dealer selling this smartphone brand \\
\hline PK & Product knowledge $(\mathrm{PK})(\alpha=0.865 ; \mathrm{CR}=0.867 ; \mathrm{AVE}=0.534)$ \\
\hline 24 & The color of this smartphone brand is durable \\
\hline 25 & The products of this smartphone brand are comfortable to use \\
\hline 26 & The smartphones of this brand are rich in colors for you to choose \\
\hline 27 & The smartphones of this brand have many materials suitable for you \\
\hline
\end{tabular}




\section{MEASURING BRAND VALUE BASED ON CUSTOMER DATA}

\begin{tabular}{|c|l|}
\hline BV & \multicolumn{1}{c|}{ Brand value $(\mathbf{B V})(\boldsymbol{\alpha}=\mathbf{0 . 8 9 2} ; \mathbf{C R}=\mathbf{0 . 8 9 5} ; \mathbf{A V E}=\mathbf{0 . 6 9 7})$} \\
\hline 28 & I am very excited and happy to use this smartphone brand \\
\hline 29 & $\begin{array}{l}\text { Although other smartphone brands may have the same qualities, I still choose this } \\
\text { smartphone brand }\end{array}$ \\
\hline 30 & I feel secure when using the smartphone of this brand \\
\hline 31 & I am satisfied with the reasonable price for the smartphones of this brand \\
\hline \multicolumn{2}{|c|}{ Cronbach alpha; CR: Composite Reliability; AVE: Average Variance Extracted }
\end{tabular}

The results of EFA analysis show there are five factors extracted at the eigenvalue of 1.153. The total variance extracted $=70.107 \%(>50 \%)$. The KMO coefficient $=0.868(>0.5)$; Bartlett test with Sig $=0.000(<0.05)$. The transmission coefficient of all the variables is greater than 0.5 . Therefore, the observed variables meet all the necessary conditions and can be used further for CFA analysis.

The CFA results show that all the standardized estimates of factor loadings are of high value. The conformity assessment criteria have the chi-squared value of 519.933 with 275 degrees of freedom and the value of $p=.000$. The relative squared value to the degrees of freedom CMIN / df is $1.891(<0.2)$. Other indicators include: GFI = $0.900(>0.9)$, TLI = $0.955(>0.9), \mathrm{CFI}=0.962(>0.9)$ and RMSEA $=0.050(<0.08)$. Therefore, this model is suitable for processing the market data. This also allows us draw a judgment on the unidirectionality of the observed variables. Regarding the convergent values, the standardized weights of all the scales are $>0.5$ and statistically significant at $\mathrm{p}<0.5$. Therefore, we can assume that the scales will achieve the convergent values.

\section{Structural Equation Model Results}

The research model covers seven research concepts, including six independent concepts: Brand awareness (BAW), Brand association (BAS), Brand equity (BE), Brand loyalty (BL), Perceptual quality (PQ), Product knowledge (PK). In contrast, the whole Brand value $(\mathrm{BV})$ is a dependent concept.

The results show that this model has a chi-squared value of 455.551 with 250 degrees of freedom $(\mathrm{p}=0.000)$. Relative squared value to the degrees of freedom CMIN/df is 1.822 $(<0.2)$. Other indicators include: GTI $=0.910(>0.9), \mathrm{TLI}=0.957(>0.9), \mathrm{CFI}=0.964(>0.9)$ and RMSEA $=0.048(<0.08)$. Therefore, this model achieved compatibility with collected information. The factors include Product knowledge $(\mathrm{PK})(\mathrm{ES}=0.345 ; \mathrm{P}=0.00)$; Brand awareness $(\mathrm{BAW})(\mathrm{ES}=0.239 ; \mathrm{P}=0.000)$; Brand equity $(\mathrm{BE})(\mathrm{ES}=0.235 ; \mathrm{P}=0.00)$; Brand loyalty $(\mathrm{BL})(\mathrm{ES}=0.220 ; \mathrm{P}=0.00)$; Brand association $(\mathrm{BAS})(\mathrm{ES}=0.200 ; \mathrm{P}=0.00)$; Perceptual quality $(\mathrm{PQ})(\mathrm{ES}=0.143 ; \mathrm{P}=0.00)$. The findings show a positive effect of the Brand value because it had the $\mathrm{P}$-values being $<0.05$, and the estimated values are normalized so that they also have positive values. This means we can accept the hypotheses $\mathrm{H} 1, \mathrm{H} 2, \mathrm{H} 3$, H4, H5 and H6 (Tab. 3). 


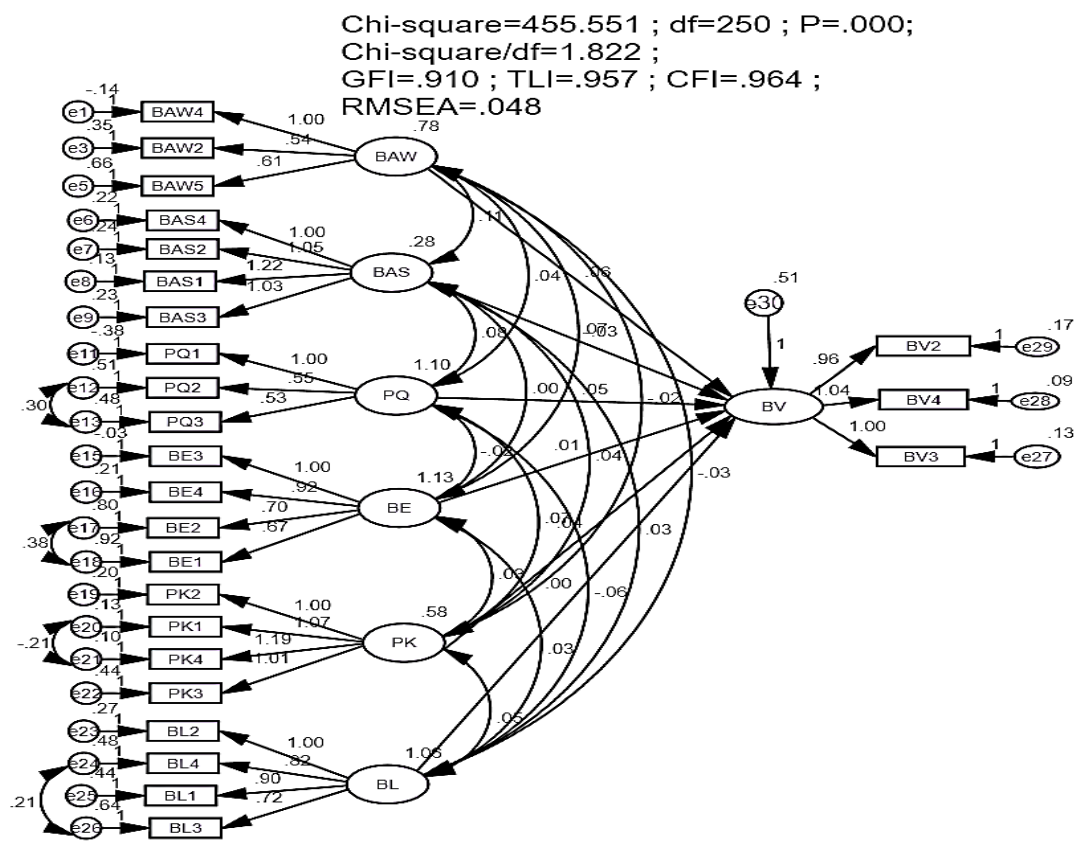

Figure 1 - The model structure after final calibration in SEM (Source: authors' own calculations in SPSS Amos 24.0)

Table 3 - Results of estimating the causal relationships between the elements of brand value (Source: Authors' own calculations in SPSS Amos 24.0)

\begin{tabular}{|c|c|c|c|c|c|c|c|}
\hline \multicolumn{2}{|l|}{} & S.E. & C.R. & P & & Label \\
\hline Relationship & Estimate & & & & \\
\hline BV & $<---$ & BAW & 0.239 & 0.058 & 0.673 & $* * *$ & Yes \\
\hline BV & $<---$ & BAS & 0.200 & 0.103 & 0.001 & $* * *$ & Yes \\
\hline BV & $<---$ & PQ & 0.143 & 0.063 & 0.639 & $* * *$ & Yes \\
\hline BV & $<---$ & BE & 0.235 & 0.083 & 0.431 & $* * *$ & Yes \\
\hline BV & $<---$ & PK & 0.345 & 0.064 & 0.636 & $* * *$ & Yes \\
\hline BV & $<---$ & BL & 0.220 & 0.063 & 0.346 & $* * *$ & Yes \\
\hline
\end{tabular}

\section{Testing the reliability of estimates by means of bootstrap}

The bootstrap method is usually used to test the model estimates, with the pattern repeatedly being $\mathrm{N}=1000$.

The estimation results for 1000 samples averaged together with the deviations are presented in Tab. 4. CR has very small absolute value, thus, it can be stated that the deviation is very low, while also being not statistically significant at the $95 \%$ confidence level. Thus, we can conclude that the model estimates can be trusted. 


\section{MEASURING BRAND VALUE BASED ON CUSTOMER DATA}

Table 4 - Results estimated by means of bootstrap, $\mathrm{N}=1000$

(Source: authors' own calculations)

\begin{tabular}{|c|c|c|c|c|c|c|c|c|c|}
\hline \multicolumn{2}{|c|}{ Relationship } & Estimate & SE & SE-SE & Mean & Bias & SE-Bias & CR \\
\hline BV & $<---$ & BAW & 0.239 & 0.058 & 0.001 & -0.033 & 0.004 & 0.002 & 0.5 \\
\hline BE & $<---$ & BAS & 0.200 & 0.103 & 0.002 & -0.009 & 0.001 & 0.003 & 3 \\
\hline BV & $<---$ & PQ & 0.143 & 0.063 & 0.001 & -0.040 & 0.002 & 0.002 & 1 \\
\hline BV & $<---$ & BE & 0.235 & 0.083 & 0.002 & 0.040 & 0.005 & 0.003 & 0.6 \\
\hline BV & $<---$ & PK & 0.345 & 0.064 & 0.001 & 0.040 & -0.005 & 0.002 & -0.4 \\
\hline BV & $<---$ & BL & 0.220 & 0.063 & 0.001 & 0.020 & -0.001 & 0.002 & -2 \\
\hline
\end{tabular}

\section{Discussion and implications}

Our research results show that Brand awareness (BAW), Brand association (BAS), Brand equity (BE), Brand loyalty (BL), Perceptual quality (PQ), Product knowledge (PK) have a direct and positive impact on the entire brand.

In particular, the impact of Product knowledge $(\mathrm{PK})(\mathrm{ES}=0.345)$, brand awareness $(\mathrm{BAW})(\mathrm{ES}=0.239)$, brand equity $(\mathrm{BE})(\mathrm{ES}=0.235)$ and Brand loyalty $(\mathrm{BL})(\mathrm{ES}=0.220)$ is quite large. This result, yet another time, shows the essential role of administrators and the importance of product knowledge, brand awareness, brand equity and brand loyalty for the overall brand value. Therefore, managers need to focus both efforts and resources of their business so that to improve brand equity, product quality, product knowledge, brand awareness of customers, and brand loyalty in the process of building brand value.

In a highly competitive smartphone market, the key to creation of a successful brand is in what customers like about the product/service of businesses. From that, the company will know how to build a program focusing on the factors that are able to increase attractiveness and/or excite the target customers.

Businesses also need to consider the spending habits of their customers and to shape their loyalty program to best suit the related demands. After that, an effective communication plan should be established with the aim to attract as many people to join the loyalty program as possible. These factors combine together will contribute to customer perception of the brand. These are the reasons why customers choose specific brands and demonstrate loyalty to them while going shopping.

Continuous, exciting experience helps connect customers with the company. When the form of relationship is already established, the messages may become much more excited. Excitement is a strong, positive emotion. When excitement is present, the company can more easily eliminate the frustration among its customers, while continuing to show the appropriate value of brands.

The results of this study determine there is a direct and positive relationship between brand awareness and brand value, meaning that if a smartphone brand is a memorable brand, 
it will be also easily recognizable in the future. This can be seen as a guarantee for success of a brand at Vietnam's smartphone market.

However, it should be noted that the correlations between brand awareness and quality perception, brand association and brand loyalty are directly and positively related to the magnitude of $0.345,0.239,0.235$ and 0.220 respectively. This implies that managers have managed to establish quite an organic relationship between the components of brand value. It is quite possible that one or several of these factors, whether very high or very low, affect the overall value of a brand, but it can also indirectly affect the whole value through the influence of the remaining factors. Therefore, in the process of building brand value at Vietnam's smartphone market, many resources are usually concentrated on the quality aspects as well as loyalty and brand associations, but not that much attention is dedicated to investment in brand equity and brand asset knowledge.

\section{References:}

Aaker, D. A., (1991). Managing Brand Equity. New York, Free Press.

Aaker, D. A. (1996). Measuring Brand Equity across Products and Markets. California Management Review, 38: 102-120.

Aperia, T., and Back, R. (2004). Brand Relations Management, Ola Hakansson, Malmo.

Davis, S. (2002). Brand Asset Management: how businesses can profit from the power of brand, Journal of Consumer Marketing, 19: 351-358.

Farquhar, P. H. (1989) Managing brand equity. Marketing Research, 1(3): 24-33.

Keller, K. L. (1993). Conceptualizing, Measuring and Managing Customer- Based Brand Equity. Journal of Marketing, 57(1): 1-22.

Kotler, P. and Levy, S. J. (1996). Broadening the Concept of Marketing. Journal of Marketing, 33(1): 10-15.

Lassar, W., Mittal, B., Sharma, A. (1995). Measuring customer based brand equity. The Journal of Consumer Marketing, 12(4): 11-19.

Levitt, T (1981)/ Marketing intangible product and product Harvard Business Review, May-June: 94102.

Sentosa, I. et al. (2012). A Structural Equation Modeling of Internet Banking Usage in Malaysia. Journal of Arts, Science and Commerce, 3 (1): 75-86.

Sharon, E.B. and Scott M.S. (1987). External Search Effort: An Investigation across Several Product Categories. Journal of Consumer Research, 14,1: 83-95.

Zeithaml, V.A. (1988). Consumer perceptions of price, quality, and value: a means-end model and synthesis of evidence, Journal of Marketing, 52,2: 2-22.

Paper submitted

Paper accepted for publishing

Paper published online
03 November 2018

12 January 2019

31 March 2019 